\title{
A Study on Mechanical and Durability Aspects of Concrete Modified with Steel Fibers (SFs)
}

\author{
Jawad Ahmad,", Aneel Manan', Asif Ali², M. Waleed Khan², M. Asim', Osama Zaid ${ }^{2}$ \\ ${ }^{1}$ Department of Civil Engineering, Military College of Engineering, Sub Campus of National University of Sciences and Technology, \\ Islamabad, Pakistan \\ ${ }^{2}$ Department of Civil Engineering, Swedish College of Engineering and Technology, Pakistan \\ ${ }^{3}$ Department of Civil Engineering, CECOS University of IT and Emerging Science, Pakistan
}

Received July 22, 2020; Revised August 24, 2020; Accepted September 29, 2020

\section{Cite This Paper in the following Citation Styles}

(a): [1] Jawad Ahmad, Aneel Manan, Asif Ali, M. Waleed Khan, M. Asim, Osama Zaid, "A Study on Mechanical and Durability Aspects of Concrete Modified with Steel Fibers (SFs)," Civil Engineering and Architecture, Vol. 8, No. 5, pp. 814 - 823, 2020. DOI: 10.13189/cea.2020.080508.

(b): Jawad Ahmad, Aneel Manan, Asif Ali, M. Waleed Khan, M. Asim, Osama Zaid (2020). A Study on Mechanical and Durability Aspects of Concrete Modified with Steel Fibers (SFs). Civil Engineering and Architecture, 8(5), 814 - 823. DOI: 10.13189/cea.2020.080508.

Copyright $\mathrm{C} 2020$ by authors, all rights reserved. Authors agree that this article remains permanently open access under the terms of the Creative Commons Attribution License 4.0 International License

\begin{abstract}
Concrete is weak in tension and strong in compression which results in brittle failure. This is obviously unacceptable for any construction materials. Thus, concrete requires some type of tensile reinforcement to balance its brittle behavior and improves its tensile strength. Adding of fibers is one of the most prevalent techniques to enhance the tensile behavior of concrete. Fiber slows cracking phenomena and increases energy absorption capacity of the structure. Majority researchers focus on mechanical performance of fiber reinforced concrete. In this research, the influence of various dosages of steel fibers $(0 \%, 1.0 \%, 2.0 \%, 3.0 \%$, and $4.0 \%$ by weight of cement) is investigated on the mechanical and durability properties of concrete. Mechanical properties such as compressive strength and split tensile strength are studied at 7- and 28-days curing. To evaluate the durability aspects of each mix, various parameters such as water absorption, acid attack resistance, and permeability are investigated. Results indicate that strength was increased up to $2 \%$ addition of steel fiber and then reduced gradually. It also indicates that, durability parameter of concrete for example water absorption, permeability, and acid attack resistance considerably improved with incorporation of steel fibers at $2.0 \%$ incorporation of steel fibers. Therefore, it is recommended to mix steel fibers up $2.0 \%$ by weight of cement to achieved maximum benefits.
\end{abstract}

Keywords Steel Fibers Reinforced Concrete, Compressive Strength, Split Tensile Strength, Water
Absorption, Permeability, Acid Resistant

\section{Introduction}

In construction industries, concrete is highest used material for its high compressive strength. But concrete has very low tensile capacity which results in abrupt failure in concrete structure. Different types of fiber are used in concrete to increase the tensile capacity of concrete under tension loading. Majority Steel fiber reinforced concrete has the capability of brilliant shock resistance, ductility, flexural strength, tensile strength, Crack arrest \& fatigue resistance.

In 1910, Porter first recommended the use of steel fibers in concrete [1]. The first research on reinforced fiber concrete in the US was performed in 1963 [2]. A general observation is that thin fibers are more impressive in reducing the width of plastic shrinkage cracks than thick fibers as reported in ACI 544.5R-10 [3]. The positive significance of steel fibers in concrete depends on many factors such as shape, length, type, strength cross section, mix design, matrix strength fiber content, \& steel fiber bond strength [4]. Between these high-performing concretes, for the benefits of low cost, easy fabrication, performance improvements, steel fiber-reinforced concrete is used extensively for engineering purpose $[5,6]$. 
However, the study showed that uneven incorporation of steel fiber would affect the fluidity and uniformity of concrete mixing and even result in fiber bonding, which eventually affects the reinforcement effect of mechanical properties" [7-9]."

Steel fibers efficiently increase the load carrying capability of slab \& also allows the structure to behave more flexible. steel fibers more than $0.38 \%$ marginally enhance the ultimate load and also improve the slab flexibility [10]. Research displayed that unequal adding of SFs will affect the concrete uniformity and fluidity in mixing \& even bonding of fiber, which ultimately influence mechanical performances [11]. steel fibers significantly improve in early as well as long term compressive strength of concrete [12-16] . Steel fibers behave as crack stoppers and not as cracks prevention. Steel fibers are known to enhance tensile capacity of post-cracking behavior [17].Steel fibers have displayed more significant effects on flexural tensile strength [18]. Experiments results indicate that increase in fiber quantity will result to improve ductility, toughness, \& strength [16, 19] . Modulus of elasticity of fiber concrete raises with increase in the fiber quantity [20]. Adding of SFs in concrete not only raise the strength but also the ductility [13].They realized that fiber increased the peak pull-out load [21].SFs can enhance the tensile strength of concrete to almost $40 \%$ [22]. Moreover, the use of fibers helps in reducing the bleeding and permeability of concrete [2326]."

A brief overview of existing literature shows that a very scarce number of studies investigated durability of steel fibers reinforced concrete. [27] Investigated the mechanical performance of fiber reinforced concrete in Pakistan. They have reported the positive influence of SFs on mechanical performance. Further research was recommended [27], to study the durability of SFs reinforced concrete. Therefore, the present study evaluates durability aspects of steel fibers reinforced concrete. Steel fibers were added in proportion $0 \%, 1 \%, 2 \%, 3 \%$ and $4 \%$ by weight of cement. Test results suggest that performance of concrete considerably improved with incorporation of steel fibers.

\section{Experimental Program}

\subsection{Materials}

\subsubsection{Cement}

Ordinary Portland cement (OPC) type-1 in accordance with American Standard of Testing Materials ASTM C150 [28] was used in the making of concrete mixes. Its chemical and physical properties are displayed in Table 2.
Table 1. Physical and Chemical Property of OPC

\begin{tabular}{cccc}
\hline $\begin{array}{c}\text { Chemical } \\
\text { Property }\end{array}$ & $\begin{array}{c}\text { Percentage } \\
(\%)\end{array}$ & $\begin{array}{c}\text { Physical } \\
\text { Property }\end{array}$ & Results \\
\hline $\mathrm{Ca} 0$ & 63.7 & Size & $\leq 75 \mu$ \\
$\mathrm{SiO} 2$ & 24.9 & $\begin{array}{c}\text { Fineness } \\
\text { Normal } \\
\text { Consistency } \\
\text { Initial }\end{array}$ & $91 \%$ \\
$\mathrm{~A} 2 \mathrm{O} 3$ & 6.4 & $\begin{array}{c}\text { Stetting Time } \\
\text { Final }\end{array}$ & $33 \mathrm{~min}$ \\
$\mathrm{Fe} 2 \mathrm{O} 3$ & 3.7 & $\begin{array}{c}\text { Stetting Time } \\
\text { Specific surface }\end{array}$ & $311 \mathrm{~min}$ \\
$\mathrm{MgO}$ & 4.5 & $\begin{array}{c}\text { Soundness } \\
\text { 28-days }\end{array}$ & $0.60 \%$ \\
$\mathrm{SO} 3$ & 0.9 & $\begin{array}{c}\text { compressive } \\
\text { Strength }\end{array}$ & $42 \mathrm{Mpa}$ \\
$\mathrm{K} 2 \mathrm{O}$ & 1.4 & \multicolumn{3}{c}{} \\
$\mathrm{Na} 2 \mathrm{O}$ & 1.2 & \multicolumn{3}{c}{} \\
\hline
\end{tabular}

\subsubsection{Steel fibers (SFs)}

Straight steel fibers were obtained by cutting binding wire into $35 \mathrm{~mm}$ long length. Its properties are given in table 2 .

Table 2. Physical Property of Steel Fibers

\begin{tabular}{cc}
\hline Physical Property & Results \\
\hline Length & $35 \mathrm{~mm}$ \\
Diameter & $0.55 \mathrm{~mm}$ \\
Aspect ratio (L/d) & 64 \\
Tensile Strength & $1345 \mathrm{Mpa}$ \\
Young's & $200 \mathrm{GPa}$ \\
Modulus & \\
\hline
\end{tabular}

\subsubsection{Aggregate}

Natural sand was used as a FA (fine aggregate) in all the mixes in SSD (saturated surface dry) condition which was obtained from local market Risalpur Pakistan. Physical properties of fine were given in the Table 3.Normal weight coarse aggregate (crush stone) with nominal maximum size $25 \mathrm{~mm}$ was used as aggregate in all the mixes in SSD (saturated surface dry) condition which was obtained from local market Risalpur Pakistan. Different tests were conducted to evaluates its physical properties. Its Physical properties were given in Table 3 .

Table 3. Physical Property of Fine and Coarse Aggregate

\begin{tabular}{ccc}
\hline Physical Property & Fine aggregate & $\begin{array}{c}\text { Coarse } \\
\text { Aggregate }\end{array}$ \\
\hline Particle Size & $4.75 \mathrm{~mm}$ to $0.075 \mathrm{~mm}$ & $25 \mathrm{~mm}$ to 4.75 \\
Fineness Modulus & 2.73 & 5.7 \\
Absorption Capacity & $4.28 \%$ & $2.18 \%$ \\
Moisture Content & $2.8 \%$ & $0.45 \%$ \\
$\begin{array}{c}\text { Bulk density } \\
\left(\mathrm{kg} / \mathrm{m}^{3}\right)\end{array}$ & 1626 & 1560 \\
\hline
\end{tabular}




\subsection{Constant Parameter}

Quantity and cement type, quantity and type of aggregates, Water cement ratio and Mix design will be kept constant throughout the study.

\subsection{Variable Parameter}

The dose of steel fiber is the variable element in all Mixes, starting from $0 \%$ to $4 \%$ by weight of cement.

\subsection{Super Plasticizer}

Chemrite-530 was used as super plasticizer because it is high range water reducing admixture and non-toxic and non-hazardous under relevant health and safety issue. Chemrite-530 is a very capable super plasticizer with a set retarding effect for production of free-flowing concrete in hot climate. The super plasticizer meets the requirements of EN 934-2 T 3.1/3 [29]. and ASTM C-494 Type F [30]. Typical properties of the super plasticizer are given as under Table 4.

Table 4. Physical Property of Superplasticizer

\begin{tabular}{cc}
\hline Property & Result \\
\hline Color & Brown \\
Relative density & 1.48 at $25^{\circ} \mathrm{C}$ \\
Chloride content & $<0.1 \%$ \\
Physical state & Liquid \\
\hline
\end{tabular}

\subsection{Tests and Size of Specimen}

ASTM C39/C39M [31]Cylinder of standard size (6x12in) will be used to measure the compressive strength at 7 days $\& 28$ days. Similar cylinders of standard size (12 $\mathrm{x} 18 \mathrm{in})$ will be cast \& tested to find their tensile strength as per ASTM standard [32].Three specimens are tested for each test at $7 \& 28$ days and the mean value of the specimens is considered as strength. For durability assessment, as per ASTM C642 [33], 50mm thick and 100mmdiameter discs are casted for water absorption test. A circular truncated cone of size $\Phi 175 \times 150 \times \Phi 185 \mathrm{~mm}$ are used to find permeability resistance as per E30-2005 JTJ [34]. For acid resistant, A 100mm cubical specimen of varying NFs mix was cured in 4\% acid (H2SO4) solution for 714 and 28 days. Acid solution was changing every week to maintain $4 \%$ concertation. The acid attacks were measured in terms of mass loss (\%) due to sulfuric acid (H2SO4) attacks.

\subsection{Sample Preparation Method}

ASTM C-31[35] method was followed for the preparation of the specimens and compaction was done manually by Roding in three layers having 25 blows per layer. A total of 60 samples having a standard size will be cast $\&$ then will be tested. To study the effect of SF (steel fiber) on the behavior of hardened and fresh concrete, five mixes are prepared. Details of the mixes are provided in the following table 5 .

Table 5. Quantification of Materials

\begin{tabular}{cccccccc}
\hline Mix & $\begin{array}{c}\text { SFs } \\
(\mathrm{Kg})\end{array}$ & $\begin{array}{c}\text { Super plasticizer } \\
(\mathrm{kg})\end{array}$ & $\begin{array}{c}\text { Compressive } \\
\text { Strength }\end{array}$ & $\begin{array}{c}\text { Split } \\
\text { Tensile } \\
\text { Strength }\end{array}$ & $\begin{array}{c}\text { Water } \\
\text { Absorption } \\
\text { Test }\end{array}$ & $\begin{array}{c}\text { Acid Attack } \\
\text { Resistance } \\
\text { Test }\end{array}$ & $\begin{array}{c}\text { Permeability } \\
\text { Resistance } \\
\text { Test }\end{array}$ \\
\hline SF-0\% & 0.0 & 4.25 & $3+3$ & $3+3$ & $3+3+3$ & $3+3+3$ & 3 \\
SF-1\% & 4.25 & 4.25 & $3+3$ & $3+3$ & $3+3+3$ & $3+3+3$ & 3 \\
SF-2\% & 8.5 & 4.25 & $3+3$ & $3+3$ & $3+3+3$ & $3+3+3$ & 3 \\
SF-3\% & 12.75 & 4.25 & $3+3$ & $3+3$ & $3+3+3$ & $3+3+3$ & 3 \\
SF-4\% & 17 & 4.25 & $3+3$ & $3+3$ & $3+3+3$ & $3+3+3$ & 30 \\
& & & & & & \\
\end{tabular}




\section{Results and Discussion}

\subsection{Harden Property}

\subsubsection{Compressive Strength}

Compressive strength is the measure of greatest compressive loading that concrete can withstand. The compressive strength test is performed under the standard procedure of ASTM as ASTM C39/C39M [31] for cylindrical samples having standard dimensions as $150 \mathrm{~mm}$ diameter and $300 \mathrm{~mm}$ length as shown in Figure 1 at the ages of 7 and 28 days.

Based on experimental test outcomes compressive strength increased as the percentage of steel fiber raised up to $2 \%$ and then decreased as displayed in Figure 2. After 28 days of curing, highest compressive strength was obtained at $2 \%$ dosage of steel fiber which was $25 \%$ higher than from reference concrete. However, beyond $2 \%$ dosage the strength was reduced.

The positive effect on compressive strength is due to the confinement of the fiber reinforcement on the specimen. Compression produces an expansion laterally and with it, a tension and shear. The tension and shear are resisted by the fibers. Therefore, compression is increased. When \% of fibers is high this confinement can reduce transversal deformation of specimen and increase its compressive strength. When increasing the steel fiber percent specially of higher dosage the process of compaction will be difficult and then the compressive strength will be reduced. The finding is in the line as per previous studies [12-16].
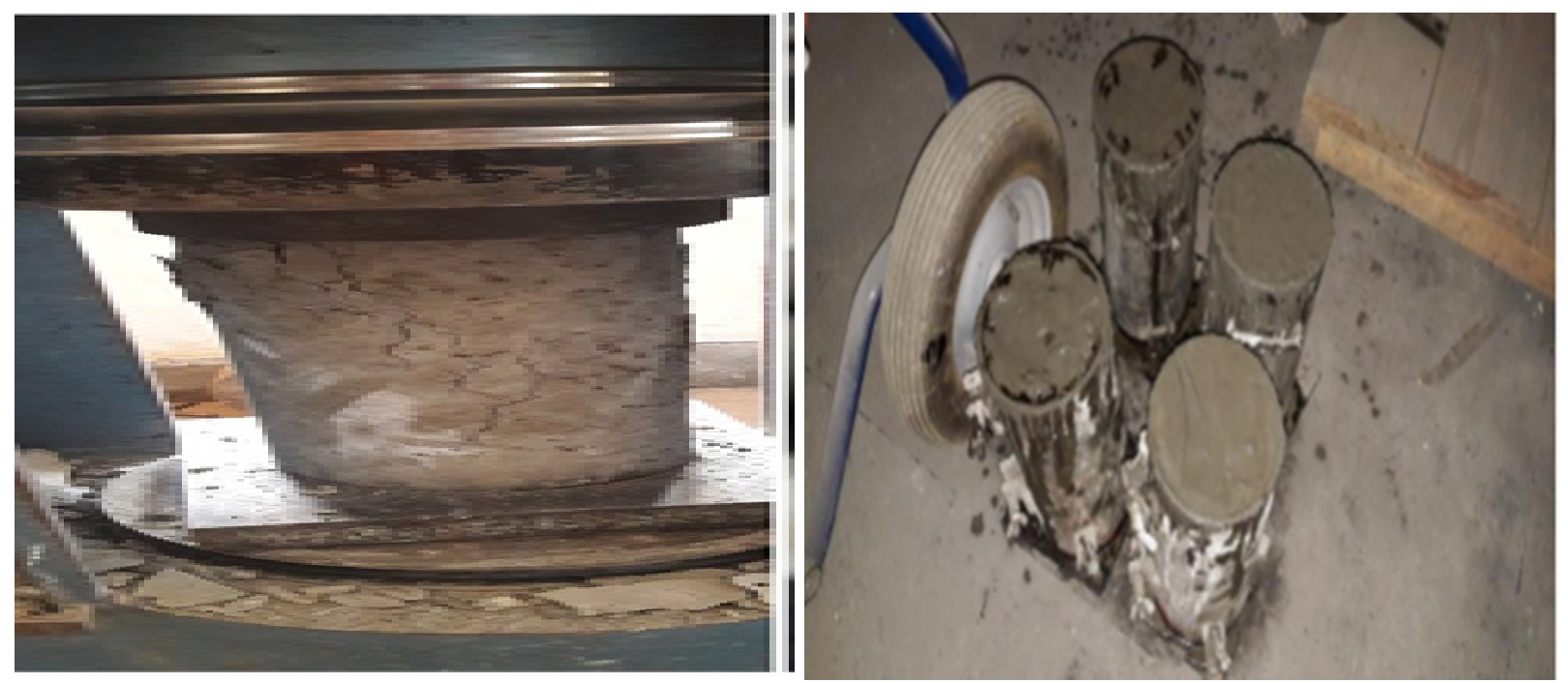

Figure 1. Casting and Setup for Compressive Strength

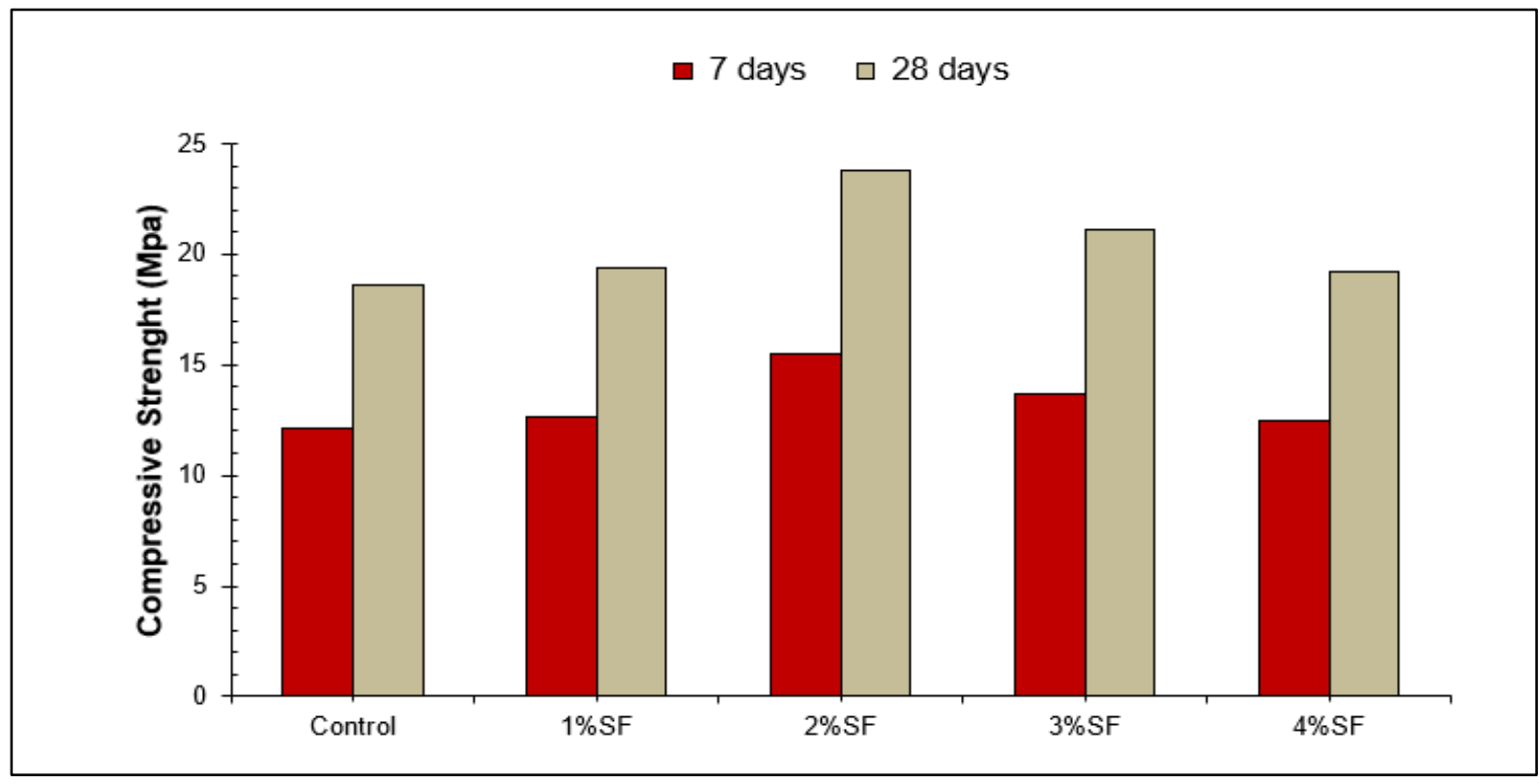

Figure 2. Compressive Strength Results 


\subsubsection{Split Tensile Strength}

Tensile strength for concrete samples is called the tensile stresses generated due to applying compressive load at which the concrete sample may fail. According to ASTM C496-71[32], split cylinder test was carried out on cylindrical specimens of $150 \mathrm{~mm}$ diameter and $300 \mathrm{~mm}$ height as shown in Figure 3 at the ages of 7 and 28 days.
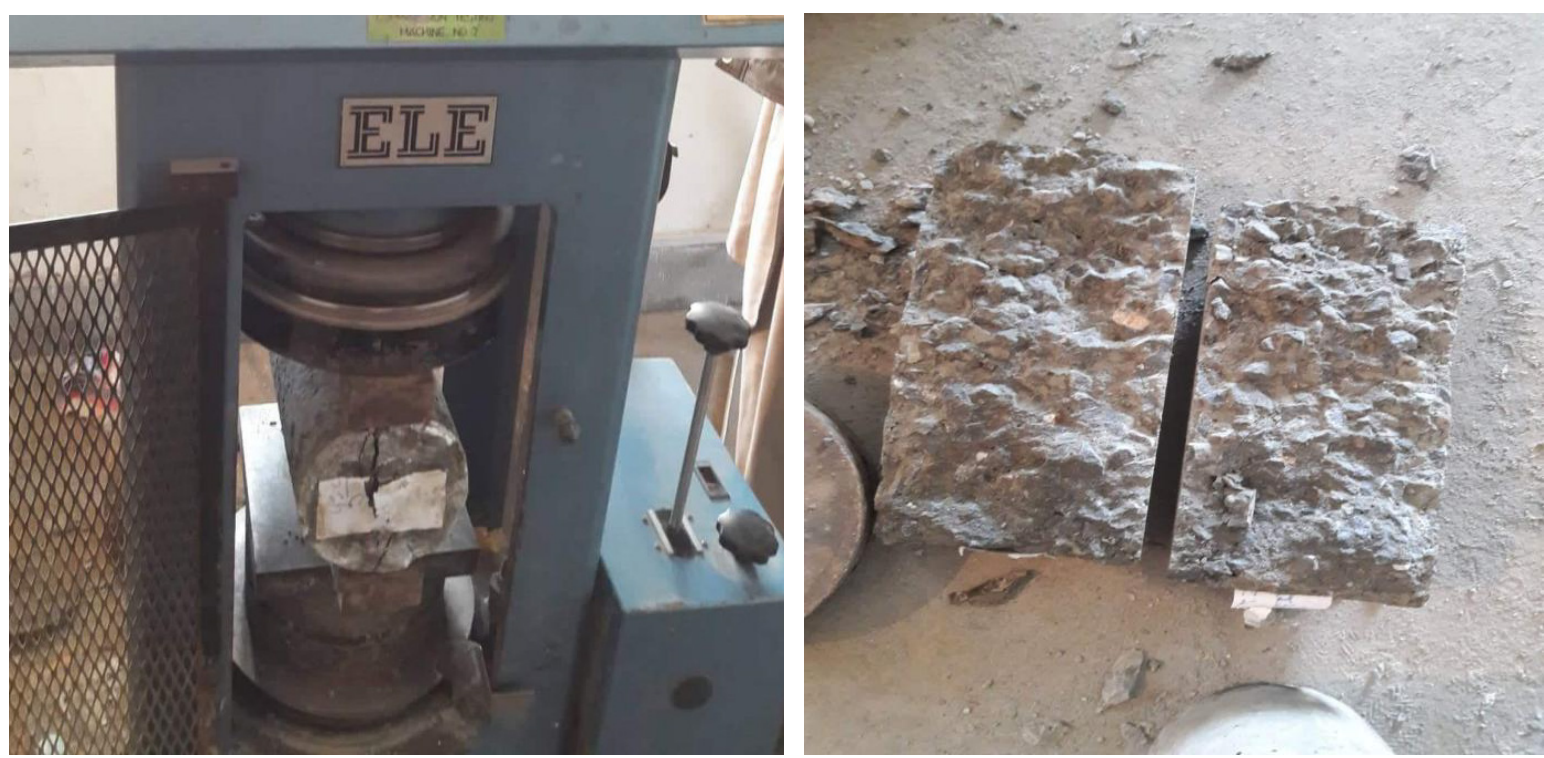

Figure 3. Setup for Split Tensile Strength

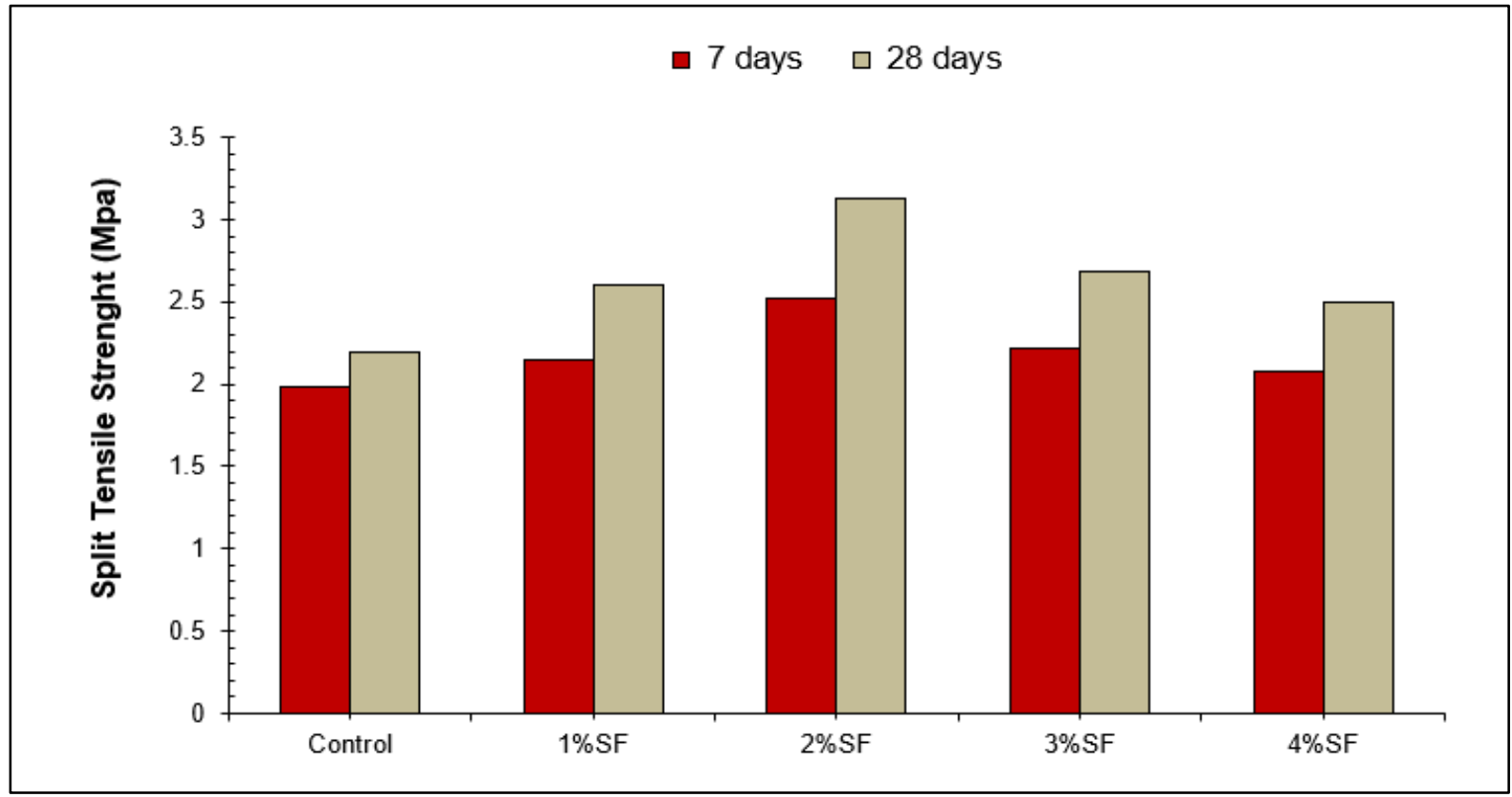

Figure 4. Split Tensile Strength Results 
Based on experimental test results split tensile strength increased as the percentage of steel fiber raised up to $2 \%$ and then decreased as displayed in Figure 4. As per previous study [17], Steel fibers (SFs) behave as crack stoppers and not as cracks prevention. Steel fibers are known to enhance tensile capacity of post-cracking behavior. After 28 days of curing, highest split tensile strength was obtained at $2 \%$ dosage of steel fiber which was $43 \%$ higher than from reference concrete. However, beyond $2 \%$ dosage the strength was reduced. Steel fibers are mixed in concrete to increase the flexibility of concrete by halting the onset of tension cracks or preventing the generation of cracks in such manner that tensile strength of (SFRC) steel fiber reinforced concrete displays better conduct than normal concrete. It can be also concluded that SFs more positively tensile strength than compressive strength [18]. The following equation can be used to predict split tensile strength from compressive strength of concrete.

$$
f \mathrm{sp}=0.53 \times \sqrt{f \mathrm{c}}
$$

Where $\mathrm{fc}(\mathrm{MPa})$ is compressive strength and $\mathrm{f}_{\mathrm{sp}}(\mathrm{MPa})$ is split tensile strength of cylindrical sample.

Comparison of predicted values with experimental tensile strength values using ACI-318.11 codes is displayed in Figure 5. Equations (1) can be used to predict values of split tensile strength which uses compressive strength. It is noticed that all empirical values locate well within the anticipated values using ACI-318.11 codes. Regression models between split tensile strength \& experimental values of compressive strength are displayed in Figure 5. A strong correlation exists $(\mathrm{R} 2>0.90)$ between both strength parameters.

\subsection{Durability}

\subsubsection{Water absorption}

Water absorption is indirect measurement of concrete durability. Mostly harmful chemicals are present in water. These chemicals react with concrete constituents, which changes the properties of concrete. Extra water present in the pore of concrete as results freeze and thaw effect because of change in temperature, which results crack of concrete. Therefore, water absorption test was conducted on 7, 14 and 28 days with varying proportion of SFs. Water absorption test results were displayed in Figure 5. A general trend indicates that water absorption capacity of fibers concrete decreased as the percentage of SFs increased. Elastic modules of normal concrete are lower than fibers reinforced concrete. So, addition of SFs would lead to increased tensile properties of concrete and as a result it would restrict the formation and development of initials cracks [36]. In other words, density of concrete is increased which would lead to water absorption of concrete decreased.

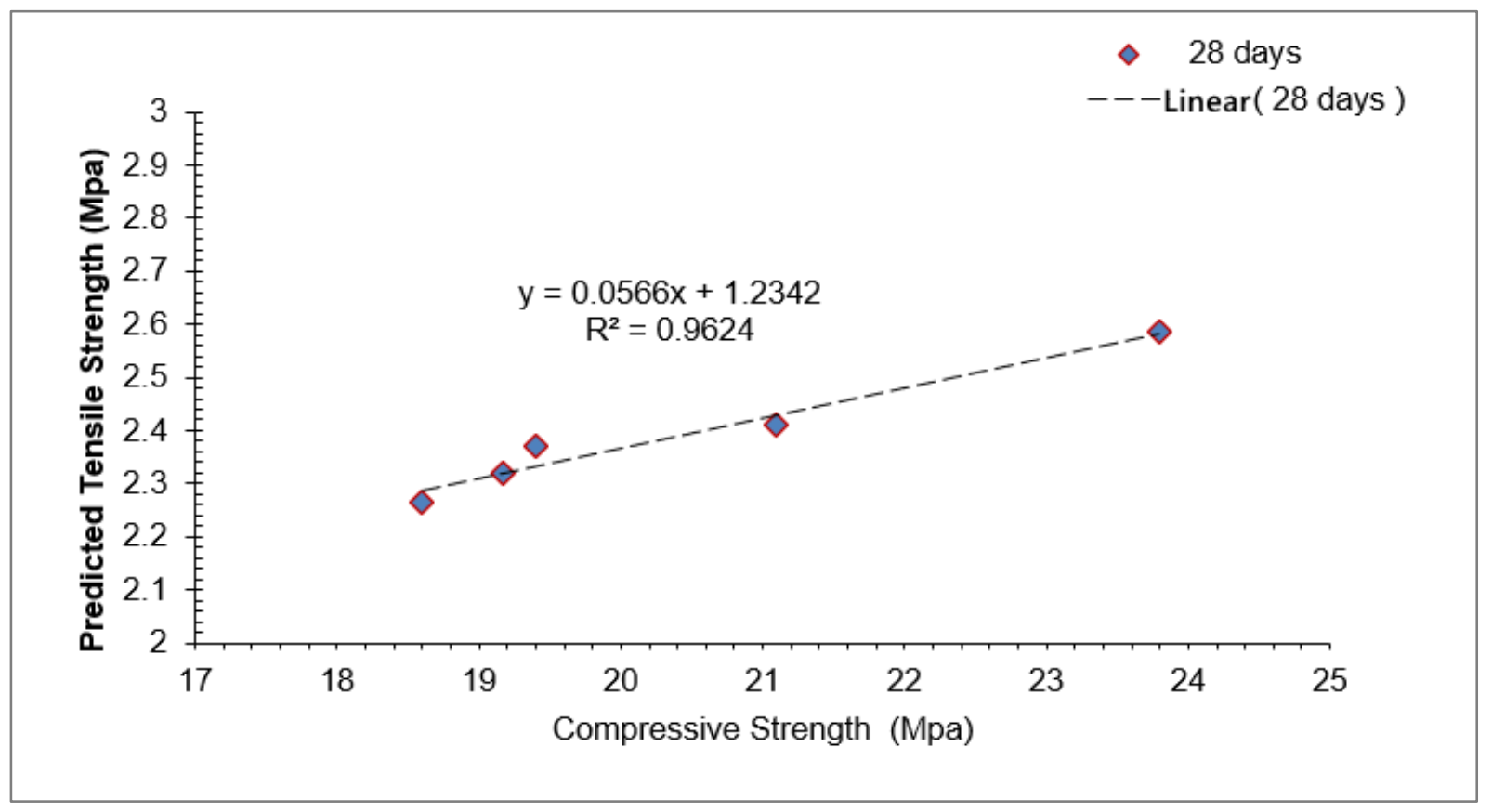

Figure 5. Co Relation Between Compressive Strength and Predicted Split Tensile Strength 


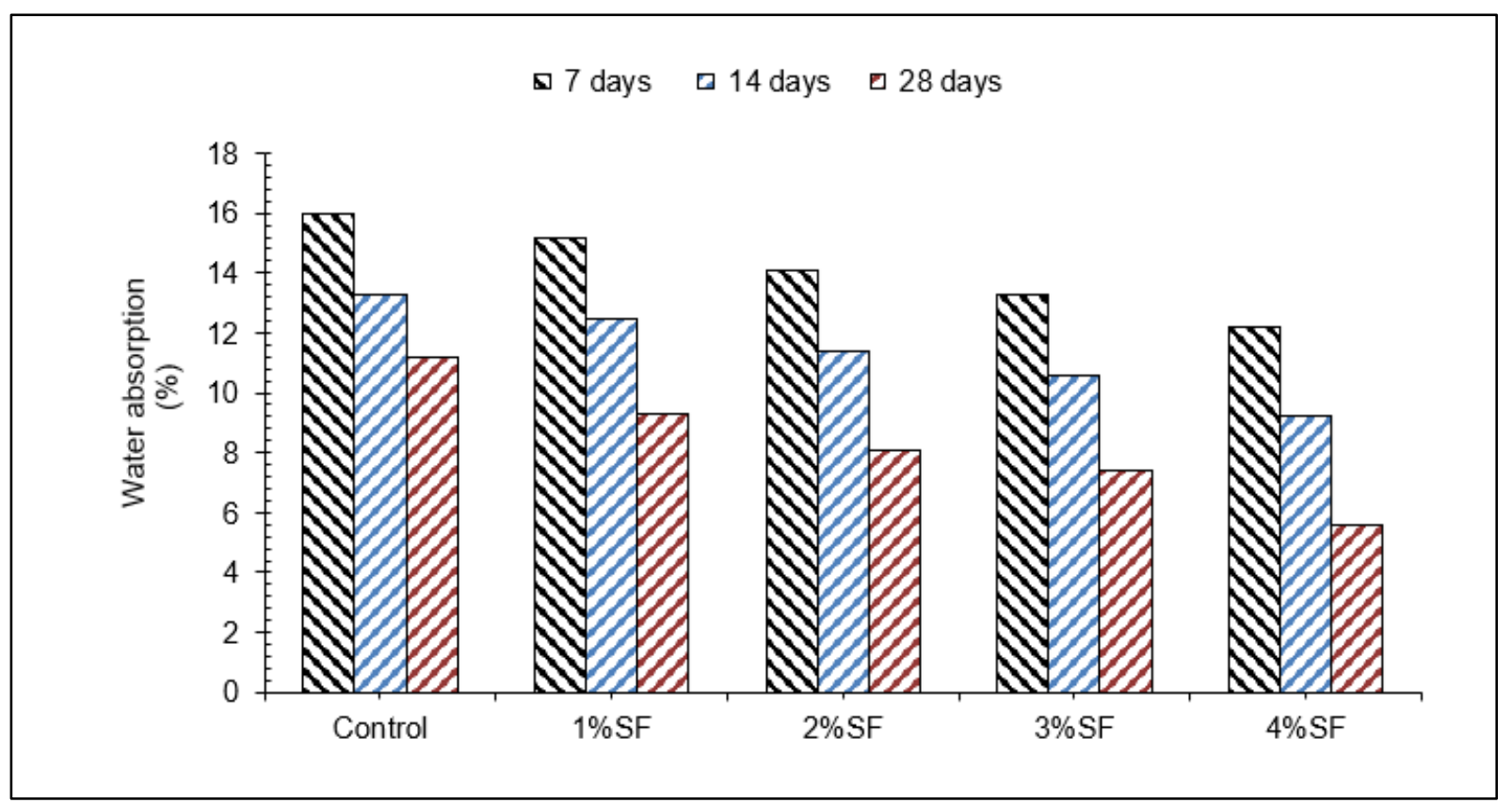

Figure 5. Water Absorption

\subsubsection{Acid resistance}

Although there are various aggressive acids, such as hydrochloric acids, nitric acids, sulfuric acids (H2SO4) and acetic acids. In this study, $\mathrm{H} 2 \mathrm{SO} 4$ was taken as a acid strike, on concrete sample with various ratios of SFs. The test results of acid resistance are shown in terms of mass loss due to sulfuric acid attack of the specimens after 7, 14 and 28 days for each blend as shown in Figure 6. It can be noted that weight loss due to sulfuric acid considerably decreases with addition of fibers. It is due to fact that addition of SFs effectively restricts the development and formation of initial cracks and decreases porosity of the concrete [36], which avert fast penetration of sulfuric acid. Erosion of concrete is basically dissolution of calcium aluminate and calcium hydroxide due to sulfuric acid [37-39]. Erosion speed will largely depend on sulfuric acid penetration rate into the concrete body and to reach calcium hydroxide and calcium aluminate. So, improvement in the porosity of concrete results increased in density of concrete due to addition of steel fibers. The raise in density would lead to less penetration rate of sulfuric acid in concrete.

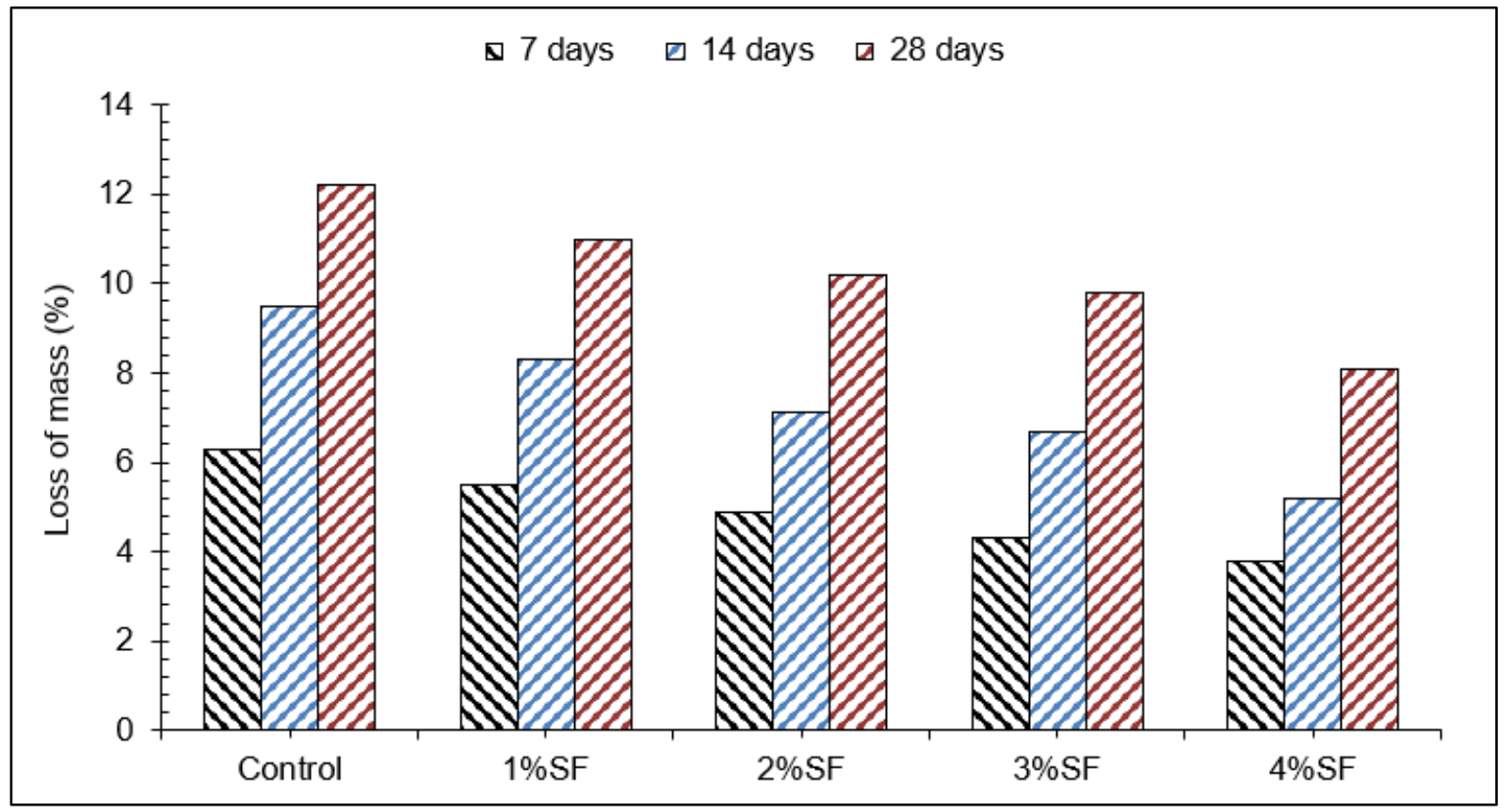

Figure 6. Acid Resistance 


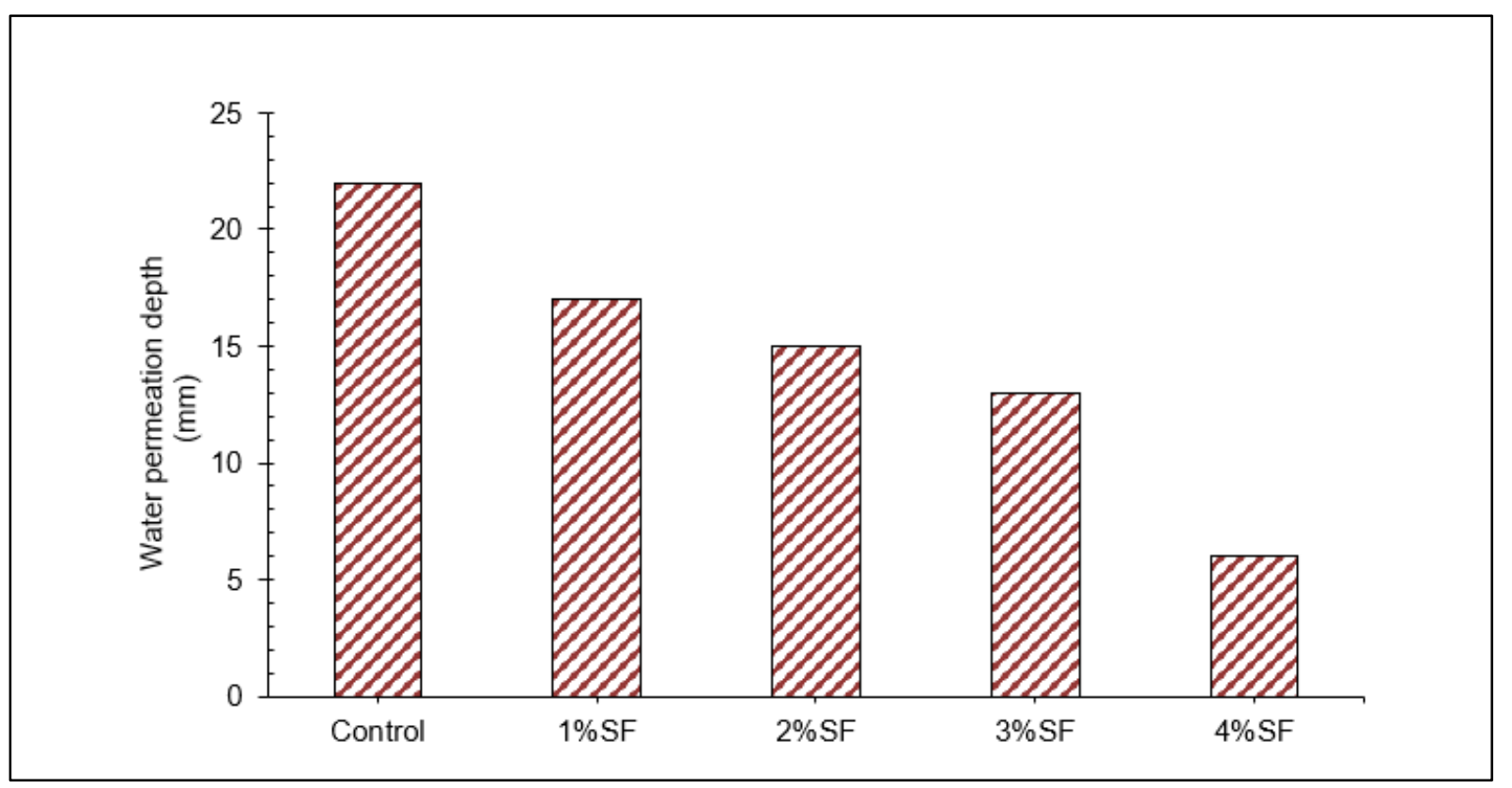

Figure 7. Permeability Permeation Depth

\subsubsection{Permeability}

Circular truncated cone specimens were used for the permeability resistance test. The dimensions of the cone were $\Phi 175 \times 150 \times \Phi 185 \mathrm{~mm}$ [34]. As well know that concrete is a porous material $[40,41]$. To characterize concrete durability, Permeability is considered as a fundamental material property as it determines the penetration rate of aggressive materials which are responsible for degradation of concrete [40].

Outcomes of permeability test were shown in Figure 7. A general trend demonstrate that permeation depth decreed as the percentage of steel fibers increased. Minimum permeation was obtained at control mix while maximum permeation depth was obtained at $4 \%$ of steel fiber (by weight of cement) $6 \mathrm{~mm}$ which is about $72 \%$ lower than control mix. It is due to fact that elastic modulus of steel fibers reinforced is much greater than that of normal concrete. Therefore, the tensile capacity of concrete increased as the percentage of steel fibers increased. This would effectively restrict initial cracks development and formation, and the porosity of the concrete could be reduced, which would be beneficial to improving the permeability resistance of concrete [36].

\section{Conclusions}

Based on experiment tests, following conclusion has been drawn.

- Strength was raised up to $2 \%$ dosage of steel fiber and beyond $2 \%$ steel fiber strength was gradually decreased. However, beyond 2\% dosage the strength was reduced but higher than from the reference concrete for all mix. It was due to the confinement of the fiber reinforcement on the specimen. When $\%$ of fibers is high this confinement can reduce transversal deformation of specimen and increase its compressive strength. However, at higher dosage compaction comes to be more difficult which results porous concrete and hence strength was reduced.

- Durability such as water absorption, acid resistant and permeability considerably improved with SFs. It is due to fact that Steel fibers (SFs) behave as crack stoppers. This would effectively restrict initial cracks development and formation, and the porosity of the concrete could be reduced. Therefore, durability aspects (water absorption, acid resistant, permeability) improved.

- From this study we can recognize that addition of SFs has enormously raised the strength as well as durability of concrete.

\section{Conflicts of Interest}

The authors have no conflict of interest to declare.

\section{REFERENCES}

[1] Ezeldin AS, Balaguru PN (1992) Normal-and high-strength fiber-reinforced concrete under compression. J Mater Civ Eng 4:415-429. https://doi.org/10.1016/j.conbuildmat.2017 .11 .005

[2] Chang D-I, Chai W-K (1995) Flexural fracture and fatigue behavior of steel-fiber-reinforced concrete structures. Nucl Eng Des 156:201-207. https://doi.org/10.1155/2018/90257 
15

[3] Banthia N (2010) Report on the physical properties and durability of fiber-reinforced concrete. https://doi.org/10.10 16/j.cemcomp.2019.103389.

[4] Behbahani HP, Nematollahi B, Farasatpour M (2011) Steel fiber reinforced concrete: A review

[5] Nielsen C V (2002) Mechanical properties for green concrete. In: in Proceedings of XVIII Nordic Concrete Research Meeting, Helsingør, Denmark

[6] Zheng Y, Cai Y, Zhang G, Fang H (2014) Fatigue property of basalt fiber-modified asphalt mixture under complicated environment. J Wuhan Univ Technol Sci Ed 29:996-1004. https://doi.org/10.1007/s11595-014-1033-1

[7] Jaivignesh B, Sofi A (2017) Study on mechanical properties of concrete using plastic waste as an aggregate. In: IOP Conference Series: Earth and Environmental Science. IOP Publishing, p 12016. https://doi.org/10.1088/1755-1315/80/ $1 / 012016$

[8] Fan FL, Xu JY, Bai EL, He Q (2011) Experimental study on impact-mechanics properties of basalt fibre reinforced concrete. In: Advanced Materials Research. Trans Tech Publ, pp 1910-1914. https://doi.org/10.4028/www.scientific.net/a mr.168-170.1910

[9] Akca AH, Özyurt N (2018) Effects of re-curing on residual mechanical properties of concrete after high temperature exposure. Constr Build Mater 159:540-552. https://doi.org/ 10.1016/j.conbuildmat.2017.11.005

[10] Sorelli LG, Meda A, Plizzari GA (2006) Steel fiber concrete slabs on ground: a structural matter. ACI Struct J 103:551. https://doi.org/10.14359/16431

[11] Zheng Y, Wu X, He G, et al (2018) Mechanical Properties of Steel Fiber-Reinforced Concrete by Vibratory Mixing Technology. Adv Civ Eng 2018: https://doi.org/10.1155/20 18/9025715.

[12] Usman M, Farooq SH, Umair M, Hanif A (2020) Axial compressive behavior of confined steel fiber reinforced high strength concrete. Constr Build Mater 230:117043. https://doi.org/10.1016/j.conbuildmat.2019.117043

[13] Sukumar A, John E (2014) Fiber addition and its effect on concrete strength. Int J Innov Res Adv Eng(IJIRAE) 1:144149

[14] Afroughsabet V, Biolzi L, Ozbakkaloglu T (2016) High-performance fiber-reinforced concrete: a review. J Mater Sci 51:6517-6551. https://doi.org/10.1590/1516-143 9.022915

[15] Mohod M V (2012) Performance of steel fiber reinforced concrete. Int J Eng Sci 1:1-4

[16] Kumar N (2015) Sangeeta,"A Review study on use of Steel Fiber as Reinforcement Material with Concrete." IOSR J Mech Civ Eng 12:95-98

[17] Lim JC, Ozbakkaloglu T (2014) Confinement model for FRP-confined high-strength concrete. J Compos Constr 18:4013058.

https://doi.org/10.1061/(asce)cc.1943-5614.0000376

[18] Deluce JR, Vecchio FJ (2013) Cracking Behavior of Steel Fiber-Reinforced Concrete Members Containing
Conventional Reinforcement. ACI Struct J 110:

[19] Khaloo AR, Kim N (1997) Influence of concrete and fiber characteristics on behavior of steel fiber reinforced concrete under direct shear. Mater J 94:592-601

[20] Gul M, Bashir A, Naqash JA (2014) Study of modulus of elasticity of steel fiber reinforced concrete. Int J Eng Adv Technol 3:304-309

[21] Shannag MJ, Brincker R, Hansen W (1997) Pullout behavior of steel fibers from cement-based composites. Cem Concr Res 27:925-936

[22] Williamson GR (1974) The effect of steel fibers on the compressive strength of concrete. Spec Publ 44:195-208

[23] Khaleel OR, Al-Mishhadani SA, Razak HA (2011) The effect of coarse aggregate on fresh and hardened properties of self-compacting concrete (SCC). Procedia Eng 14:805813. https://doi.org/10.1016/j.proeng.2011.07.102

[24] Zhu W (2020) Permeation properties of self-compaction concrete. In: Self-Compacting Concrete: Materials, Properties and Applications. Elsevier, pp 117-130

[25] Pereira ENB, Barros JAO, Ribeiro AF, Camões A (2004) Post-cracking behaviour of selfcompacting steel fibre reinforced concrete. https://doi.org/10.1617/14058

[26] Islam GMS, Gupta S Das (2016) Evaluating plastic shrinkage and permeability of polypropylene fiber reinforced concrete. Int J Sustain Built Environ 5:345-354. https://doi.org/10.1016/j.ijsbe.2016.05.007

[27] Khan A-R, Zahra T (2014) Study of properties of steel fiber reinforced concrete (SFRC) for possible applications in Pakistan

[28] Cement AP ASTM C150 of the following type: 1. Concr which will be contact with Sew Type II, Moderate Sulfate Resist 2:

[29] EN TS (2009) 934-2 “Admixtures For Concrete, Mortar and Grout-Part 2: Concrete Admixtures; Definitions, Requirements, Conformity, Marking and Labelling." $\mathrm{Br}$ Stand Inst

[30] High-Range W-RA, Admixture R ASTM C 494/C 494M. Type $\mathrm{F}$

[31] C39/C39M A (2003) Standard test method for compressive strength of cylindrical concrete specimens. Annu B ASTM Stand

[32] Designation A (1976) C496-71. Stand Method Test Split Tensile Strength Cylind Concr Specimens

[33] C642-13 A (2013) Standard test method for density, absorption, and voids in hardened concrete. West Conshohocken, PA ASTM Int

[34] E30-2005 JTJ (2005) Test methods of cement and concrete for highway engineering test methods of materials stabilized with inorganic binders for highway engineering. Chinese Stand. Des.

[35] Specimen CT ASTM C 31; one set of four standard cylinders for each compressive-strength test, unless otherwise directed. Mold store Cylind Lab test specimens Except when field-cured test specimens are required 
[36] Huang G, Xie X (2011) Experimental study on the effect of nano-SiO 2 to durability in hydraulic concrete. Yellow River $33: 138-140$

[37] Kurda R, de Brito J, Silvestre JD (2019) Water absorption and electrical resistivity of concrete with recycled concrete aggregates and fly ash. Cem Concr Compos 95:169-182

[38] Şahmaran M, Yaman İÖ, Tokyay M (2009) Transport and mechanical properties of self consolidating concrete with high volume fly ash. Cem Concr Compos 31:99-106. https://doi.org/10.1016/j.cemconcomp.2008.12.003.

[39] Aydın S, Yazıcı H, Yiğiter H, Baradan B (2007) Sulfuric acid resistance of high-volume fly ash concrete. Build Environ 42:717-721. https://doi.org/10.1016/j.buildenv.200 5.10 .024

[40] Phung QT, Maes N, De Schutter G, et al (2013) Determination of water permeability of cementitious materials using a controlled constant flow method. Constr Build Mater 47:1488-1496.https://doi.org/10.1016/j.conbui ldmat.2013.06.074

[41] Qin Y, Zhang M, Mei G (2018) A new simplified method for measuring the permeability characteristics of highly porous media. J Hydrol 562:725-732. https://doi.org/10.1016/j.jhy drol.2018.05.047 